\title{
Innovation practices success in China: The use of innovation mechanisms in Chinese SOEs
}

\author{
Liqin Ren, Koos Krabbendam, Petra de Weerd-Nederhof
}

\begin{abstract}
Purpose: The climate for technical innovation has been improving in the past few years in China. This paper describes a case research concerning technical innovation practices success in three Chinese state-owned enterprises (SOEs) in the manufacturing industry. This is executed by applying a technical innovation audit tool based on 'Western' good practices.
\end{abstract}

Methodology: Studies on technical innovation in the Chinese SOEs started in the 1990s, but most investigations in this field were based on statistical survey and mathematical modelling. In this research, case study research method, including such strategies as open-ended, in-depth questions, intensive interviews and observations, are applied for the validity of information.

Findings: The data and results reveal that the investigated Chinese SOEs have already some mechanisms for innovation in place. But there is still room for improvement and enhancement with respect to the effect on innovation success. It is also concluded that benchmarking (through the application of the technical innovation audit tool) does guide the Chinese management toward deciding which innovation mechanisms to adopt so as to provide the basics for innovation success. Additionally, based on the case studies the interesting conclusion could be drawn: In the context of the Chinese economy in transition, the case companies with less openness to the market (i.e. with high government involvement) have a more widespread use of innovation mechanisms. 
Practical Implication: The last finding seems to contradict the positive relationship between market focus and innovativeness as suggested in 'Western' innovation management theories. For clarification we relate this to the way the SOEs deal with their adaptive cycle, thereby considering their way of dealing with (increased) complexity as compared to 'Western' companies (complexity absorption versus reduction). The considered cases are embedded in the institutional setting of China in transition. Therefore, the conclusions and findings enrich the theory of transition by revealing the point that entering an open market abruptly may not be the solution for SOEs, which are rooted in a socialist economy, to become more competitive and more innovative. This was mostly elaborated through the influence of the two main stakeholders (i.e. government and customer/end user) on the openness of the SOEs and their use of innovation mechanisms in China, the largest socialist system of the world.

Originality/Value: This paper is based on a doctoral research project, containing reliable, first hand data from the practice.

Keywords: Innovation; State-owned enterprise (SOE); Case study; Stakeholder

\section{Introduction}

After two decades of gradual, piecemeal reform and opening-up, the economic environment of China has been changing from the centrally planned economic system to a more Western-like open market system. With the reform and China's entry into the World Trade Organization (WTO) in particular, the status of the mainstream of the socialist economic system and the main contributors to the government's revenue are 
changing. This means that the state-owned enterprises (SOEs) are now confronted with fierce challenges from the non-state sectors (such as the private economy, the township and village enterprises (TVEs) and the foreign-funded enterprises).

Management of technology in China has roughly experienced three phases. Firstly, before the reform and opening-up policy in 1978, China had long been in a self-closed situation except for some technologies introduced from the former Soviet Union and East Europe in the 1950s. The whole country followed the basic tenets of "acting independently and with the initiative in one's own hands; reconstructing through one's own efforts". The government set up technology standards and platforms for industries and let the SOEs design and produce, with no R\&D activity involved in an enterprise. One of our case companies (i.e. LocoCo) can be regarded as a good example of this period. LocoCo was firstly founded as a locomotive repairing works. With the Chinese government importing the first locomotive from the former Soviet Union in the 1950s, little by little LocoCo began to own such technologies and gradually developed its own technology. LocoCo became, and still is the (semi-) monopolistic locomotive producer and supplier in the Chinese markets. In the second phase (early 1980s till mid-1980s), the Chinese state-owned manufacturing enterprises imported a large number of technologies under the support of the government, which saw the focus of technology management in this period as technology selection and project implementation (i.e. technology transformation) from abroad. Those imported technologies are product designs; manufacturing techniques and equipment; production management techniques (including quality assurance); auxiliary equipment; testing techniques and devices and standards (Gu, 1999). The third phase started in the mid-1980s till the late 1990s, the focus was on 
the localization of imported technology, absorbing and assimilating technology from abroad. Thus the core of technology management in Chinese manufacturing industry during this period was imitation and partly improvement. Since the beginning of the $21^{\text {st }}$ century, the Chinese firms are trying to construct the core competence and the indigenous innovation capabilities of their own. This could be regarded as the start of a fourth phase.

With many SOEs losing their market share in the past decade, the SOEs and the Chinese government have been seeking to better understand management of technical innovation, in order to get out of this dilemma. In the mid-1990s, the issue of technological innovation has been called on by the Chinese government. During the late 1990s, this issue has been put on many Chinese firms' agenda, drawing practitioners' as well as scholars' attention in studying innovation management in the Chinese context (see Gao, 1997; Fu, 1998; Liu, 2001).

Based on a comprehensive literature study and their own empirical research and experience, Bolwijn and Kumpe (1990) developed an evolutionary model of Western manufacturing firms. This model describes the evolvement of large-scale manufacturing firms from the 1960s to the 1990s in terms of market requirement and performance criteria, from efficient firm via quality firm and flexible firm to innovative firm. According to Bolwijn and Kumpe (1990): “... the (Western) innovative firm since the 1990s is most successful with its capabilities of creating new demand and innovating products and processes in a short time". A relatively similar evolution may be recognized in the phases described above for the Chinese SOEs. Hence, it may be concluded that more attention should be paid in gaining knowledge about the SOEs' effectiveness of management of technical innovation in the changing context of China. 
Numerous Western authors have provided an answer to the questions of why to innovate and how to innovate (see for example, Burgelman et al., 1996; Tushman and Anderson, 1997; Tidd et al., 1997; Radnor and Robinson, 2000; Brockhoff et al., 2000). The question here is what insights of Western theories on good practices in management of technical innovation can contribute to the knowledge about the effectiveness of management of technical innovation in the changing context of Chinese SOEs. In regard to the transition from a centrally planned system to a market economy, many scholars argue that the management setting in China is changing, and a holistic viewpoint is needed to study the management of technical innovation in the Chinese context (see, for example, Fu, 1998; Liu and Gao, 1999).

However, there are not many researches have been done concerning technical innovation in the Chinese context. Also, the research method is relatively singular. One example can be seen from Gao (1999). Gao's (1999) research data were based on the 6 times of questionnaire, which were carried out by the Economics and Management Research Institute of Tsinghua University, the leading institute in China. Supplementary data were from China (science and technology) statistical yearbooks. The author himself used mathematical statistical method for the analysis. Another example is Wang et al. (2002). Without stating what research method(s) they used in their study, in their article they put forward strategies for large and medium state-owned enterprises' technological innovation. Wang et al. (2002) advise: "properly introduce advanced technology and equipment; put emphasis on assimilating and absorbing; establish and perfect interior innovation mechanism which is propitious to enterprise's technological innovations." 
The above literature brought us the impetus to set up our objective of this research as, to explore the technical innovation status of the SOEs and the possibilities for the application of (Western) good practices in management of technical innovation to the Chinese SOEs. In view of the fact that the Chinese enterprises are following the evolution process of the Western innovative firms, we aim to investigate the extent that innovation mechanisms are in use in the Chinese SOEs, by applying a technical innovation assessment tool that is based on Western good practices.

This article is structured as follows. After this Introduction part, it continues to describe the methods used in this research, on which three case companies are selected and how the technical innovation audit tool developed by Chiesa et al. (1996) are used for data of the technical innovation status in the three Chinese SOEs. Information was also collected through triangulation methods (Jick, 1979) in an attempt to examine more deeply the cultural and behavioural activities in influencing the Chinese SOEs' technical innovation capabilities, and to validate the empirical results obtained via the use of the technical innovation audit tool. The empirical data are presented in a qualitative way, by applying the guide by Miles and Huberman (1984). In the concluding section it is discussed that Chinese SOEs have some innovation mechanisms in place, but more could be done to adapt to the world level. Benchmarking (through the application of the audit tool) may guide management in adopting more and other appropriate innovation mechanisms as the basics for successful innovations. We also found that in the transition economy of China, SOEs with less openness to the market (i.e. with high government involvement) has had a more widespread use of innovation mechanisms and vice versa. This finding seems to contradict the positive relationship between market focus and 
innovativeness as suggested in 'Western' innovation management theories. The analysis to the case companies also enriches to a certain extent the theory of transition. It reveals that being open to the market is not the solution for SOEs to be more competitive and more innovative. In this largest socialist system of the world, the main stakeholder (i.e. government) still plays an important role in the openness of the SOEs and in their use of innovation mechanisms. To apply this point to a broader population of enterprises in China, more studies on both SOEs and non-SOEs need to be done, which indicates our future research.

\section{Methods}

\section{Case study for this research}

Studies on technical innovation in the Chinese SOEs started in the 1990s (Fu, 1998), but most investigations in this field were based on statistical survey and mathematical modelling. However, the explanation of quantitative findings and the construction of theory based on those findings will ultimately have to be based on qualitative understanding (Meredith, 1998). Questionnaires and models are constrained by rigid limits, and hard to analyse the software in management of innovation, e.g., human behaviour (Clark and Fujimoto, 1991). Whereas case studies lead to new and creative insights, development of new theory, and have high validity with practitioners - the ultimate user of research (Voss et al., 2002). Yin (1994) argues that the case study is preferred in examining contemporary events, and when a "how" or "why" question is 
being asked about a contemporary set of events over which the investigator has little or no control. Case research enriches not only theory, but also the researchers themselves. Following Voss et al.'s (2002) statement, "through conducting research in the field and being exposed to real problems, the creative insights of people at all levels of organizations, and the varied contexts of cases, the individual researcher will personally benefit from the process of conducting the research." We would believe a case study approach is very important for this research work to examine more deeply the cultural and behavioural activities in influencing the Chinese SOEs' technical innovation capabilities.

To keep the case research consistent and the data reliable, triangulation methods (Jick, 1979) were conducted in this study. Besides the Western technical innovation audit tool, intensive interviews with open-ended, in-depth questions and observations were applied. In doing so, we tried to keep all information from diverse research methods to be in line with each other.

\section{A Western technical innovation audit tool}

The technical innovation audit developed by Chiesa et al. (1996) is based on their process model (see Figure 1), which addresses the managerial processes and the organizational mechanisms through which innovation is performed. The model identifies four core processes: concept generation, product innovation, process innovation, and technology acquisition; and three enabling processes: the deployment of human and financial resources, the effective use of appropriate systems and tools, and senior management 
leadership and direction. The outcome from these core and enabling processes is performance in terms of innovation and the resulting competitiveness in the marketplace.

(Take in Figure 1)

Their technical innovation audit incorporates an extensive Western literature on good practices in management of technical innovation, and, after thorough field-testing, it has been widely implemented in numerous UK companies. The use of the tool has helped those companies to identify relevant innovation mechanisms, develop innovation performance measures and audit innovation capability as reported in Chiesa et al. (1996). Chiesa et al. state that the process of innovation is strongly related to market focus involving the continuous monitoring of customers, competitors and market trends. They believe that the four core processes are inter-related, not isolated, to any innovation, and their process-based technical innovation model indicates that market focus is related to a firm's innovation success. This seems to suggest that their audit tool can be applied to firms that are market-oriented or want to be market-oriented. To facilitate communication and sharing of Western good practice knowledge with the Chinese managers during the process of our fieldwork, we chose this audit tool for the assessment of the management of technical innovation (status quo) of the case companies, namely, LocoCo, BusCo and MotorCo in central China.

Sample selection 
In this research, three state-owned manufacturing enterprises were selected as the case companies. They produce different products and have different production technologies, and focus on different markets with different sizes. They are based in the central part of mainland China. This selection was to avoid the case companies being in the (economically) developed east area or in the less developed west region of mainland China.

Among the selected samples, one (i.e. LocoCo) ranked the top 500 industrial SOEs in China, another (i.e. BusCo) ranked the top ten of its business scope and the third (i.e. MotorCo) the top five producer of the like product. The first sample company employed around 10,000 people, and the second and the third employed over 2,400 and 6000 people respectively. All three shared the same historical background and similar stakeholder compositions as traditional state-owned manufacturing companies.

The three case companies' profiles are elaborated in Table I.

(Take in Table I)

\section{Process of data gathering}

To ensure that comparable data was collected from each sample SOE, the same technical innovation assessment tool, which was translated into Chinese for this purpose, was delivered to the key informants. To validate the results out of the assessment tool and to get informed responses from the three companies, intensive interviews with open-ended, in-depth questions were also carried out to the key people. In chronological order, LocoCo, MotorCo and then BusCo were studied. The interviewees were knowledgeable 
about their firms' strategic orientations and who took direct control of technological innovation activities of their enterprises. The people concerned were the three functional managers (i.e. the Production Manager, the R\&D/Product Development Manager and the Sales and Marketing Manager) and one (vice) General Manager or vice President in Technology.

Detailed explanation to the technical innovation scorecard was given to the (vice) General Manager or vice President in Technology and the functional managers on how to fill it out. For example, each item has four scales ranking from one to four, and scale four is considered to be the 'world class' innovation performance (see Table II). The use of the four-scale ranking presented us with bias because companies came to fill in a high score to make their company look not too bad, which has to do with the Chinese traditional behaviour of "preserving of face". Therefore we stressed consistently the needs for the use of innovation mechanisms instead of the individual performance of their company, and we kept on refreshing the scales with semi-structured, in-depth questions.

(Take in Table II)

Information through within-case triangulation methods was compared with their scoring of the innovation scorecard. By using some triangulation methods (Jick, 1979), we tried to keep all information from diverse research methods to be in line with each other. Based on our discussions with the informants of the case companies, the half point scale was introduced (see for example, scale 2.5 in Figure 2). The informants found namely that the innovation practices of their company were sometimes in between of two 
full-point scales. In combination with data out of the technical innovation scorecard and the triangulation methods, the current technical innovation situation of the three SOEs is depicted in Figure 2. A distinctive phenomenon in Figure 2 is that LocoCo has more use of innovation mechanisms and a low score in market focus, whereas BusCo and MotorCo on the other hand, have less use of innovation mechanisms, higher score in market focus, and a rather low competitiveness in the market.

(Take in Figure 2)

\section{Results to date}

The key information out of the three case companies, which is considered to be the results of the technical innovation scorecard and the triangulation methods, was collected. Miles and Huberman (1984) have written a guide for the analysis of and display of qualitative data. In brief, they encourage the use of tables to display key information, which more specifically for innovation research is also recommended by Radnor and Robinson (2000). Therefore, The key technical innovation mechanisms within the three case companies are displayed in Tables III and IV, which are mostly based on the results out of the technical innovation scorecard and the intensive interviews. The items in the two tables (Table III and Table IV) are the key points of Chiesa et al.'s (1996) innovation process model.

(Take in Table III and Table IV) 
Table III and Table IV summarize the use of innovation mechanisms in the three Chinese SOEs. LocoCo shows that it has already most innovation mechanisms in place; BusCo shows that it has only some mechanisms in place; and MotorCo has even fewer in place.

According to Chiesa et al., management of technical innovation is a process which consists of all four core processes and three enabling processes. Based on the technical innovation scorecard results and our in-depth interviews we may conclude that LocoCo's has enabling processes and mechanisms in place. LocoCo has more use of innovation mechanisms in their core processes, but still, there are no multi-disciplinary teams with early involvement in a new project or new product development. Furthermore, crossfunctional teamwork is weak; and there is almost no industrial design for market demand. Also based on the technical innovation scorecard results and our in-depth interviews we may conclude that BusCo and especially MotorCo still lack most technical innovation mechanisms in both core processes and enabling processes. It seems that these two companies do not wish to take innovation risks because they think they are short of capital and they cannot afford to fail. There is no new product planning, but they follow the popular models in the world with an inward-looking technology strategy. Also they miss most enabling processes such as innovation funds and human resources. We were told, for instance, that MotorCo's R\&D staff in 2000 even dropped from 60 to 40 . In the company newspaper, we read that MotorCo's employees were complaining about the leadership of the top management. 
Therefore, it is argued that although Chinese SOEs have already some mechanisms for innovation in place, with respect to the effect on innovation success, there must be more improvement and enhancement.

\section{Discussion}

\section{Dynamics of stakeholder composition of the three SOEs}

In her PhD thesis, Ren (2004) discussed the dynamics of stakeholder composition of Chinese SOEs in terms of the stakeholders' power, legitimacy and urgency (see Mitchell et al., 1997). The stakeholder compositions of the three case companies were similar, but stakeholders own different attributes of power, legitimacy and urgency, especially the influence of two main stakeholders' roles. These stakeholders, the government and the end user or customer, are considered influential to three case companies' effectiveness of technical innovation management. The government/end user or customer influence on the different case companies showed a high/low influence on LocoCo, and a low/high influence on BusCo and MotorCo. This seems to be opposite to the situation in the Western world. Although the stakeholder situation of MotorCo and BusCo is playing in an open market and they are experiencing fierce competition, it does not lead to an increased use of innovation mechanisms. On the other hand, in the case of LocoCo, where the government still plays an important role, we found more use of technical innovation mechanisms. 
(Take in Figure 3)

Based on our studies on innovation mechanisms used in the case companies and the stakeholder influence discussed above, we realize that there are essentially three dimensions that indicate the current innovation situation of the three SOEs. This illustrates the relationships between the change in stakeholder situation and the use of innovation mechanisms: Use of innovation mechanisms, Openness to the market and Government protection (see Figure 3). On the one hand, LocoCo has the highest use of innovation mechanisms and a low position in market focus. On the other hand, BusCo and MotorCo have lower government protection and higher openness to the market (thus a higher market orientedness might be expected), but with less innovation mechanisms. In our research, the intriguing finding was that in the transition economy of China, the higher the openness to the market and lower protection of the government, the less innovative and competitive the company. To put it in other words, BusCo and MotorCo seem to have to "defend" their own "turfs". More precisely, LocoCo is in a (semi-) monopoly sector with a lower openness to the market and higher protection of the government in various aspects, but its innovation performance is high. For MotorCo, it is the other way around. The interface of the openness to the market and government interference, and the innovation performance of BusCo are in between of LocoCo and MotorCo.

In Figure 3 we see that government protection is confronted with market openness. LocoCo only has to deal with the government protection for financing, orders, projects, etc; whereas BusCo and MotorCo have to deal with the open market and the government 
interference (e.g. personnel appointment). Thus there at least exists an administrative problem (see Miles et al., 1981). Based on our research we can roughly draw the conclusion that large-scaled Chinese SOEs like LocoCo, which in the past decades have saved cumulative technology and equipment and still enjoy the government's privileges in financial appraisal and industrial policies, may take the lead among the Chinese SOEs to be innovative in the short run. Other large and medium SOEs already 'forced' to increasing market-orientedness in order to secure operational effectiveness and thus survival will be staying in the dilemma situation. To take the risk of investing in innovation may be a means of ensuring longer term strategic flexibility, but they may loose out on short term performance because of it. This lack of innovation may be seen as to "wait for the death". This seems to oppose the Western literature and theory in which market-orientedness is supposed to lead to increased use of innovation mechanisms. The Chinese government's control on SOEs', such as personnel appointment and interference on managerial issues, have been found to negatively influence the vitality of the SOEs, especially in the aspects of technological innovation capability and creativity. This leads to our conclusion that in the Chinese traditionally planned (socialist-style) economy, social, political and institutional effects still have dominant impact on SOEs' innovation competitiveness. Major stakeholders' influence, like the government, on technical innovation is prominent, and this is especially true for the transitional economic situation of China. Such stakeholders are important for the management of technical innovation of the Chinese SOEs because they provide the SOEs with scarce resources, which determine the smooth implementation of technical innovation. 
What we could find was the shift of stakeholder composition of the SOEs. But, as indicated before, we found no evidence that SOEs that were forced to become more open to the market, became more innovative in product and process than those who are still in the semi-closed market despite of industrial maturity. Surprisingly, the government opened the market and let the companies alone in financing, but still interferes the SOEs with personnel appointment, managerial instructions and so on. The research also substantiates that incurring debt motivates managers to sacrifice long-term investment in favour of short-term cash flow. This is mainly the result of the government's interference of personnel appointment in a more competitive and less protected situation.

In the innovation process model of Chiesa et al., for example, the market trend is also seen as the main driving force for carrying out technical innovation, indicating that Western firms in competitive situations take innovation as a means to increase competitiveness in the marketplace. One would expect that with the opening of the market, the Chinese SOEs, when confronted with the market situation, would generate industrial technological innovation within the firms and bring more orders from the market more or less automatically. But this did not happen in our three cases, and it even seems to go the other way around. Looking for explanations for all these facts, we first turn to Miles et al.'s (1981) theoretical framework for the analysis of organizations in their adaptive processes.

\section{Adaptive processes at the case companies}

With China's reform and opening-up policy, the three SOEs have had to adapt themselves to the changing economic environment, although each is doing in a different 
pace. In mature organizations, management must solve each of these problems (i.e. the entrepreneurial problem, the engineering problem, and the administrative problem) simultaneously, and such organizational problems in the adaptive cycle are the critical determinants of organizational structure and process, and further the strategic types (i.e. Defenders, Analyzers, and Prospectors) of organizations (see Miles et al., 1981). According to the characteristics of the strategic types of organizations identified by Miles et al., the three case companies in this research could be firstly mapped into the category of Defenders. Their success comes primarily from efficiently serving a stable domain and whose primary risk is that of ineffectiveness. Started as a Defender, BusCo and MotorCo held the administrative problem of how to maintain strict control of the organization in order to ensure efficiency. As a result, their administrative system as well as technology are ideally suited to maintain stability and efficiency, but are not well suited to locating and responding to new product or market opportunities. In the process of adaptation, these two SOEs were confronted with the open market situation, and they managed to adjust their entrepreneurial problem and engineering problem from a Defender to an Analyser, with the characteristic of attempting to minimize risk while maximizing the opportunity for profit. On the one hand, especially in the design of their administrative system and organization, they still have the characteristic of a Defender, trying to keep the current fairly stable set of products and customer or client group; on the other hand, they wish to expand new products or new markets. That can be the reason why product imitation for them is accomplished only when the most successful product or market innovations developed by prominent Prospectors are adopted. 
Miles et al. (1981) state, "The successful Analyser must be able to respond quickly when following the lead of key Prospectors while at the same time maintaining operating efficiency in its stable product and market areas." However, BusCo and MotorCo's use of innovation mechanisms and their competitiveness in the market, and MotorCo's in particular, were showing the adaptive cycle of a Reactor - responding inappropriately to environmental change and uncertainty, performing poorly as a result, and then being reluctant to act pro-actively in the future. According to Miles et al., this was because of the "lagging" aspect of the administrative system in the adaptation process. In other words, in the process of adaptation, BusCo and MotorCo's entrepreneurial problem and engineering problem were moving towards the characteristics of an Analyser, but their administrative problem made their performance lagging behind.

However, Miles et al.'s theory does not seem to be workable to LocoCo. Also started as a Defender, in its adaptive process during the economic environment in transition in China. But LocoCo's privileged position, i.e. being in a (half) monopoly industry with the protection of the government, provided it with advantages to have the tendency to become a Prospector. There is no risk for LocoCo to conduct new project and new product development. Maintaining the reputation as an innovator in product and market development is as important as, perhaps even more important than high profitability. Therefore LocoCo's prime capability is that of finding and exploiting new product and market opportunities. This finding might be interpreted to be opposite to Miles et al., who seem to suggest that in a non-open environment there would be no need for pro-active innovation. They say for example "Unless an organization exists in a "protected" environment such as monopolistic or highly-regulated industry, it cannot continue to 
behave as a Reactor indefinitely (Miles et al., 1981)". It seems that without an explicit need for it, LocoCo is already pro-actively concerned with its strategic flexibility by employing innovation mechanisms. BusCo and MotorCo are defending their domestic market, while LocoCo is trying to expand for international market share, which fits for the characteristics of an Analyser. As demonstrated in Bolwijn and Kumpe's evolution model, most proactive Western firms are already over 30 years developing from efficient firms till today's innovative firms (but most are still 'lagging behind' in other phases). Our findings clearly illustrate that Chinese SOEs cannot do it by just a quantum leap, just because the Chinese government artificially and abruptly opens up the market.

Although the framework of Miles et al. does not fully explain our findings, putting the research results in terms of their framework does help to interpret the findings better. We are now able to discuss the peculiarities of how the case companies deal with the adaptive processes from the viewpoint of two characteristics of China's social system. On the one hand the way of dealing with (increasing) complexity in China which differs from the 'West', and on the other hand the fact that it is a socialist system in transition.

\section{Complexity absorption versus complexity reduction}

Organizations are adaptive systems in complex environments (Boisot and Child, 1999). In their study, Boisot and Child stated that historical factors have shaped the nature of complexity in China, with the social tradition and political economy generating high levels of cognitive complexity and pushing China's economic organizations in the direction of complexity absorption through more intense systems of relationships. Moreover, China is the worlds largest socialist system, the norms and regulations 
developed in this system, and the strong networks waved among the clans and families and friends made this society even more complex.

Miles et al.'s theory could not explain why the three case companies were in such different situations of their adaptive cycles compared to their Western counterparts. However, Boisot and Child's complexity absorption and complexity reduction helps to shed a different light on the matter. Unlike Western firms that are familiar with the strategy of complexity reduction, the Chinese companies are good at complexity absorption, among many other things, and culturally more attuned to the complex Chinese context. The inclination to deal with complexity by way of absorption may be part of the explanation why BusCo and MotorCo face much more turbulence and change in their stakeholders' composition and influence. Apart from 'defending' themselves to survive in the short run, they have not been able to move towards the internal stimulation of using more innovation mechanisms, and the benefit from which would be expected only in the longer run. The more protected and shielded environment from LocoCo may have provided the right climate in which complexity absorption can foster strategic flexibility and adopting innovation mechanisms. LocoCo's codification and abstraction in this climate may have better facilitated the process of diffusion and thus partly account for better performance. The question is whether complexity reduction in the cases of BusCo and MotorCo might have led to different results. 
In their technical innovation process model, Chiesa et al. indicate that firms that are market-oriented would be more innovative. "Market-oriented" firms to a certain extent refer to those that are proactive to adapt to dynamic and continuous changes in the environment. The Chinese socialist economy in transition may be compared to the developments in Germany when the socialist East was re-united with the capitalist West. Specifically we cite work from Kogut and Zander concerning the "twin" Zeiss companies (Kogut and Zander, forthcoming), which technically are more or less identical: Zeiss Jena (East Germany) and Zeiss Oberkochen (West Germany) with their patent records from 1950 to 1990 . However, "Zeiss Jena gradually developed considerable technological capabilities, ...technologically viable firms can fail in the initial period of transition from socialism to capitalism (Kogut, and Zander, forthcoming)". Based on these experiences, and our findings at LocoCo, the Chinese government might be better advised to let the SOEs go very carefully with their technical innovation during its socialist system in transition. China now seems to be a rather opened up market, but this openness is a governmental activity. The government artificially created the open market for the Chinese SOEs by introducing competitions and regulations, but leaving the SOEs structure and managerial process with little change, would not automatically result in more innovation initiatives of the SOEs.

The analysis of the three Chinese SOEs in this article clarifies a phenomenon happened in the socialist economy in transition. Innovation in LocoCo, to a certain extent, is an extension of government plan since it is the government that initiates large innovation projects. This political arrangement or planned innovation economically protected LocoCo from market competition so that it became relatively innovative, 
among others. Whereas early market-oriented SOEs, like BusCo and MotorCo in this research, failed to be innovative without sufficient government protection for some time because their products were not critical to the nation's strategic development. In addition, the pressure coming from political interference did not harm the protected firm's top management, but frustrate the enthusiasms of those managers whose companies were more exposed in the competitive market. These results have important implications for the theory of transition.

The findings of the study and Chiesa et al.'s good practice benchmarking idea also provided the SOEs' managers with fresh insight into their ongoing innovation activities. Some realized which innovation mechanisms should adopt so as to provide the basics for innovation success. All the three companies assured that external factors influence the organization's innovation. The government's role in operation and management is gradually declining, but the consistent administrative control (i.e., personnel appointment) to the SOEs constrained the SOE managers' innovation initiatives. Managers believed that basically they the internal innovation activities were under their control, but external factors had influence on the innovativeness of their firms. They also agreed that with effective management and incentive mechanism, good innovation outcomes could be realized, and company indigenous technology development ability would accelerate as it develops its own technology generating capability.

\section{Further research}


By doing case research, the authors realized that the major stakeholders of Chinese SOEs have had significant influences on their openness to the market, their technical innovation capabilities and use of innovation mechanisms. More case studies need to be conducted to see how this is applicable to other Chinese firms. Factors such as the extent of market openness, the government influences, company size, innovation input and output, etc. will be considered. Not only the state-owned and non-state-owned, but also the emerging phenomenon of Chinese enterprises operating abroad could also be studied to compare with the research results.

In order to test the research results, the authors submitted a research proposal together with a Chinese institute for a further research. The joint research proposal (titled Management of Technical Innovation of the Chinese Firms in the Transition Economy) has recently been approved by the Royal Dutch Academy of Sciences (Netherlands) and the Ministry of Science and Technology (China). This future research will focus on specific stakeholders' influence on the company's openness to the market and innovation mechanisms. This is to obtain knowledge about the way management of technical innovation taking place in China, to what extent and in what respect it differs from the Western 'best practices' and if these differences can be explained by the way Chinese management teams deal with environmental complexity. This includes whether and how Chinese enterprises, which wish to globalise in the world market, can make positive use of the strategies of complexity absorption or perhaps should be advised to turn to the strategies of complexity reduction in operating in a different cultural and institutional environment. The expected research results are aimed to contribute to the theory of transition, to provide insights for appropriate government policies in China's socialist system in transition, and to help Chinese enterprises in their transition to market oriented companies. 


\section{References}

Boisot, M. and Child, J. (1999), "Organizations as adaptive systems in complex environments: The case of China", Organization Science, Vol 10 No 3, May-June, pp. $237-52$

Bolwijn, P.T. and Kumpe, T. (1990), "Manufacturing in the 1990's - productivity, flexibility and innovation”, Long Range Planning, Vol 23 No 4, pp. 44-57

Brockhoff, K.K., Pearson, A.W., de Weerd-Nederhof, P.C. and Kerssens-van Drongelen, I.C. (2000), Technology readings in management: A selection from 10 European Doctoral Summer Schools, Twente University Press, Enschede, the Netherlands Burgelman, R.A., Maidique, M.A. and Wheelwright, S.C. (1996), Strategic management of technology and innovation ( $2^{\text {nd }}$ edn), Boston: Inwin/Mcgraw-Hill Chiesa, V., Coughlan, P. and Voss, C. (1996), "Development of a technical innovation audit”, Journal of Production Innovation Management, 13, pp. 105-36

Clark, K. and Fujimoto, T. (1991), Product development performance, Harvard Business School Press, Boston, Mass.

Fu, J. (1998), Technological innovation (Ed.), Tsinghua University Press, Beijing

Gao, J. (1997), Analysis on innovation in the Chinese firms, Tsinghua University Press, Beijing

Gu, S. (1999), China's industrial technology, Market reform and organizational change, Routledge, London and New York 
Jick, T.D. (1979), "Mixing qualitative and quantitative methods: Triangulation in action", Administrative Science Quarterly, Vol 24, pp. 602-11

Kogut, B. and Zander, U. (2000), "Did socialism fail to innovate? A natural experiment of the two Zeiss companies", American Sociological Review, Vol 65 No 2, pp. 169-190

Liu, W. and Gao, M. (1999), The restructuring of state-owned enterprises in transition, Shanghai Far East Press

Liu, Y. (2001), Enterprise innovation, China Economics Press, Beijing Meredith, J. (1998), "Building operations management theory through case and field research", Journal of Operations Management, Vol 16, pp. 441-54

Miles, M.B. and Huberman, A.M. (1984), Qualitative data analysis: A source of new methods, Sage, London

Miles, R.E., Snow, C.C., Meyer, A.D. and Coleman, Jr., H.J. (1981), “Organizational strategy, structure, and process (1978)", re-printed in M. Jelinek, J.A. Litterer and R.E. Miles (Ed.), Organization by design: Theory and practice, Business Publications, Inc, Plano, Texas 75075

Mitchell, R.K., Agle, B.R. and Wood, D.J. (1997), “Toward a stakeholder identification and salience: Defining the principle of who and what really counts", Academy of Management Review, 22, pp. 203-25

Radnor, A. and Robinson, J. (2000) "Benchmarking Innovation: A short report", Creativity and Innovation Management, Vol 9 No 1, pp. 3-13

Ren, L. (2004), Management of technical innovation in Chinese state-owned enterprises:

Case studies from a stakeholder perspective, $\mathrm{PhD}$ Thesis, University of Twente, Enschede, the Netherlands 
Tidd, J., Bessant, J. and Pavitt, K. (1997), Managing innovation: Integrating technological, market and organizational change, Wiley, Chichester, England

Tushman, M.L. and Anderson, P.C. (1997), Managing strategic innovation and change: a collection of readings, New York: Oxford

Voss, C., Tsikriktsis, N. and Frohlich, M. (2002), "Case research in operations management”, International Journal of Operations \& Production Management, Vol 22 No 2, pp.195-219

Wang, Q., Cao, Z. and Zhang, M. (2002), “Some problems and proposals on innovation mechanism of large and medium state-owned enterprises", in $\mathrm{Xu}, \mathrm{Q} ., \mathrm{Wu}, \mathrm{X}$. and Chen, J. (Ed.), Management of technology and innovation in the $21^{\text {st }}$ century, Proceeding of $3^{\text {rd }}$ International Symposium on Management of Technology and Innovation (ISMOT '02), Zhejiang University Press, Hangzhou, pp. 15-17

Yin, K. (1994), Case study research: Design and methods $\left(2^{\text {nd }}\right.$ edn), Sage Publications, California

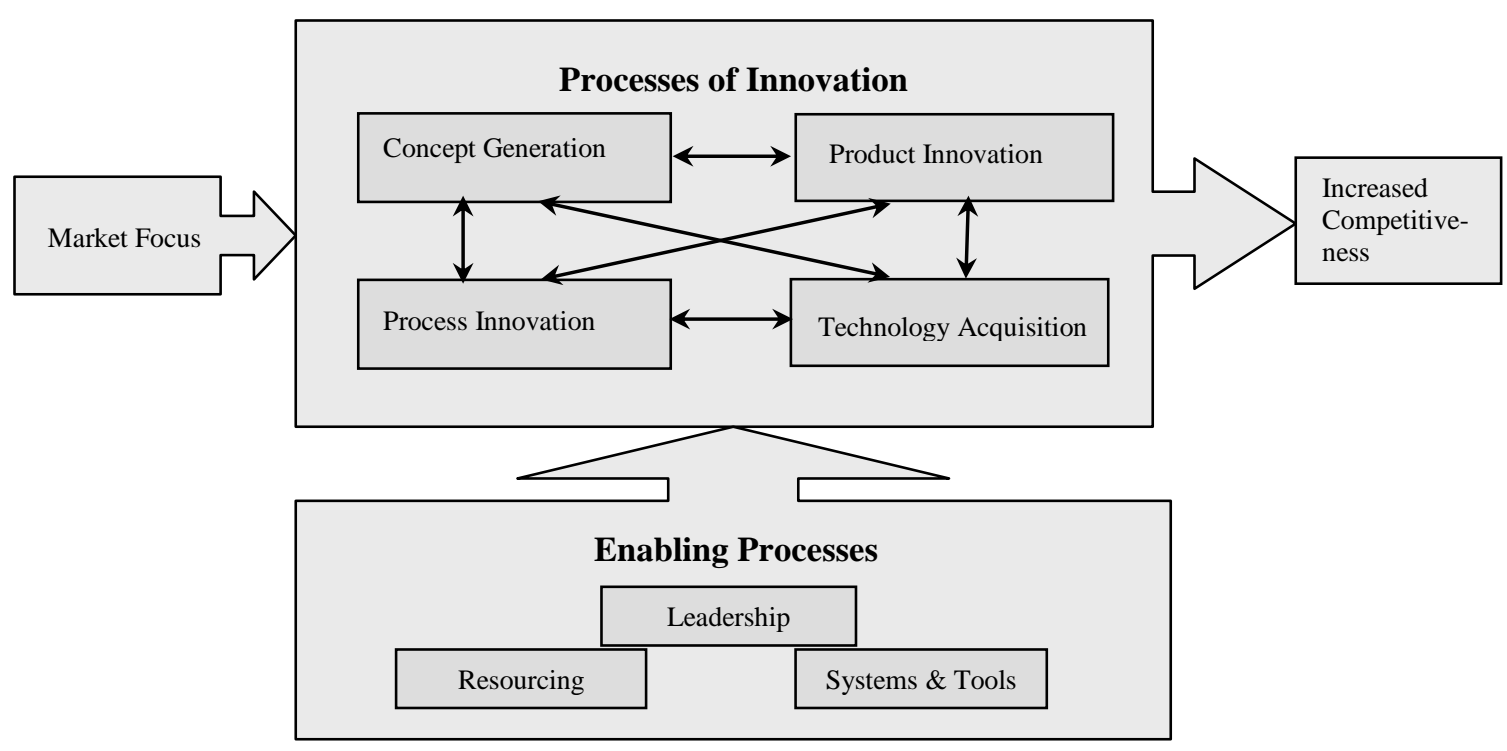

Figure 1. A Process-based Innovation Model (Source: Chiesa et al., 1996) 
Table I. Profile of Case Companies

\begin{tabular}{ll}
\hline Name in Short & Innovation Features \\
\hline LocoCo & Top management involvement \\
& $\begin{array}{l}\text { Strong R\&D, including a national-level R\&D Center } \\
\text { Diverse sources of technology } \\
\text { An outward-looking focus for innovation process } \\
\text { Enjoy government privilege, no need to worry about orders }\end{array}$ \\
BusCo & $\begin{array}{l}\text { Customer-oriented production and marketing } \\
\text { Some technology links with a local university } \\
\text { 70\% are group buyers, innovation is to meet their needs and tastes }\end{array}$ \\
MotorCo & $\begin{array}{l}\text { Strong imitation strategy for the latest model(s) in the world } \\
\text { Good distribution channels } \\
\text { Years of profit losing makes the top management thinking of strategic } \\
\text { change in core business due to some government limitations in selling its } \\
\text { products in cities }\end{array}$ \\
\hline
\end{tabular}

Table II. An Example of the Technical Innovation Assessment Scorecard (Source: Chiesa, et al., 1996)

\begin{tabular}{|c|c|c|c|}
\hline 1 & 2 & 3 & 4 \\
\hline \multicolumn{4}{|l|}{ Process Innovation } \\
\hline \multicolumn{4}{|l|}{ Generating Process Innovations } \\
\hline $\begin{array}{l}\text { Serious differences between } \\
\text { process requirements and } \\
\text { technology available. }\end{array}$ & $\begin{array}{l}\text { No manufacturing strategy: } \\
\text { process technology bought } \\
\text { off the shelf. }\end{array}$ & $\begin{array}{l}\text { Manufacturing strategy } \\
\text { ensures that process } \\
\text { capabilities support market } \\
\text { needs. Investment in } \\
\text { improving existing and } \\
\text { developing technologies. }\end{array}$ & $\begin{array}{l}\text { Strong links between product } \\
\text { and process development. } \\
\text { Information on new process } \\
\text { technology actively sought and } \\
\text { new processes tested to gain } \\
\text { experience. }\end{array}$ \\
\hline \multicolumn{4}{|l|}{ Implementation of New Processes } \\
\hline No attention to implementation. & $\begin{array}{l}\text { Implementation seen as } \\
\text { installation. }\end{array}$ & $\begin{array}{l}\text { Cross-functional } \\
\text { implementation teams }\end{array}$ & $\begin{array}{l}\text { Implementation teams stay } \\
\text { together into full production to } \\
\text { ensure learning and } \\
\text { improvement. Active } \\
\text { involvement. Active } \\
\text { involvement of suppliers. }\end{array}$ \\
\hline \multicolumn{4}{|l|}{ Continuous Improvement } \\
\hline If it isn't broken, leave it alone. & $\begin{array}{l}\text { Focus on maintenance of } \\
\text { processes, not improvement. }\end{array}$ & $\begin{array}{l}\text { Need for continuous } \\
\text { improvement of processes } \\
\text { recognized - primarily the } \\
\text { responsibility of process } \\
\text { engineering function. }\end{array}$ & $\begin{array}{l}\text { Work teams encouraged to } \\
\text { identify opportunities for } \\
\text { improvement. Use of wide } \\
\text { range of internal and external } \\
\text { data to support improvement. }\end{array}$ \\
\hline
\end{tabular}




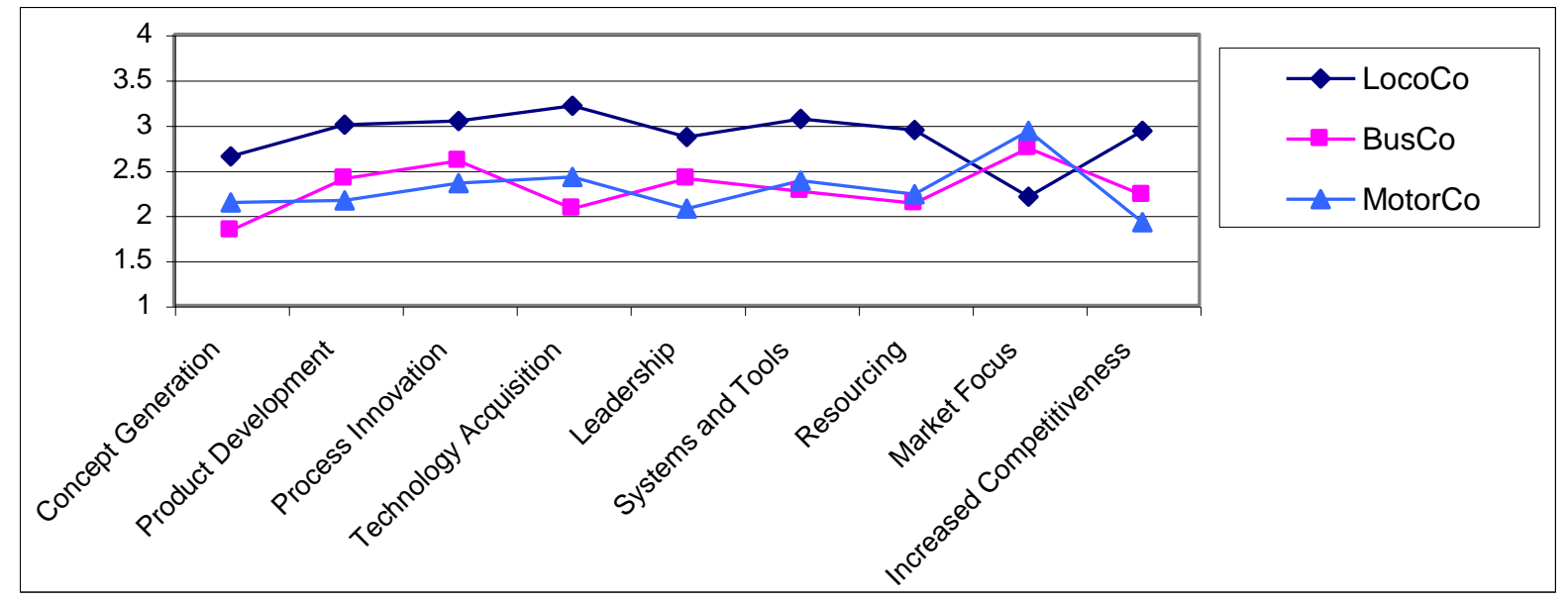

Figure 2. A Linear Description of the Innovation Mechanisms Used in the Three SOEs.

Table III. The Core Processes of the Innovation Process

\begin{tabular}{lccc}
\hline & LocoCo & BusCo & MotorCo \\
\hline Product innovation planning & & No & N/A \\
Innovation rewards & Yes & Yes & No \\
Innovation risk-taking & No risk) & No & No \\
$\begin{array}{l}\text { Use of multi-discipline teams } \\
\text { with early involvement }\end{array}$ & No & No & No \\
Cross functional teamwork & Some & No & No \\
Employees involved in & Yes & Some & No \\
continuous improvement & & & Some \\
Industrial design & No & No & Some \\
$\begin{array}{l}\text { Diversified technology sources } \\
\text { Technology strategy identified }\end{array}$ & Outward-looking & Inward-looking & No \\
New ideas from: & R\&D & Customer demands & Competitors \\
& Global competitors & Suppliers & Marketing \\
& Local customer needs & Competitors & Special magazines \\
& & & \\
\hline
\end{tabular}

Note: According to Chiesa et al. (1996) the core processes of the innovation process consist of concept generation, product innovation, process innovation and technology acquirement. 
Table IV. The Enabling Processes of the Innovation Process

\begin{tabular}{|c|c|c|c|}
\hline & LocoCo & BusCo & MotorCo \\
\hline Top management involvement & Yes & Yes & No \\
\hline Clear innovation goals & Yes & (Short-term) & (Short-term) \\
\hline $\begin{array}{l}\text { Management attention to } \\
\text { encourage innovation }\end{array}$ & Yes & No & No \\
\hline Training program for staff & Yes & No & No \\
\hline $\begin{array}{l}\text { Innovation process properly } \\
\text { funded }\end{array}$ & Yes & No & No \\
\hline $\begin{array}{l}\text { Intranet and internet used to } \\
\text { facilitate information and } \\
\text { design }\end{array}$ & Yes & Some & Some \\
\hline
\end{tabular}

Note: According to Chiesa et al. (1996) the enabling processes of the innovation process consist of leadership, resourcing and systems and tools.

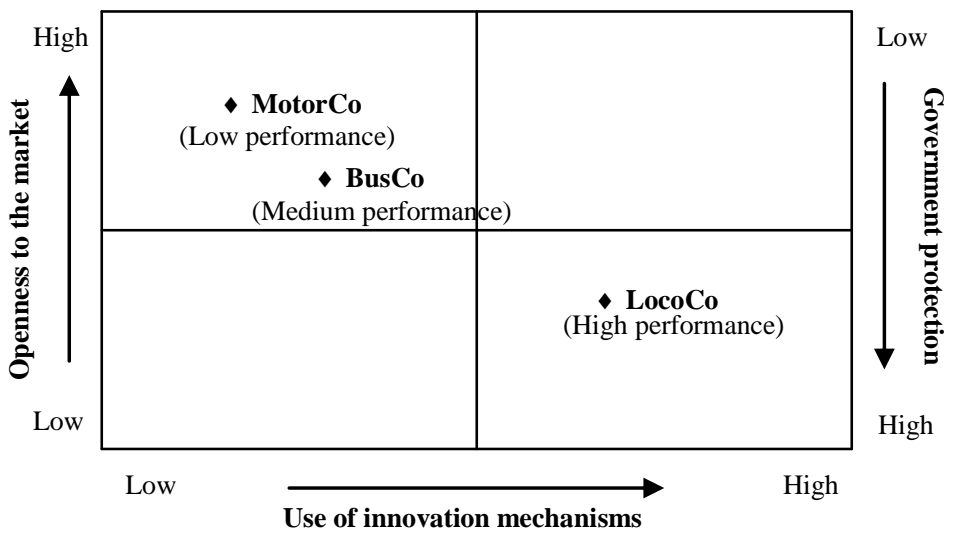

Figure 3. The Relationships between Openness to the Market and Government Protection and the Use of Innovation Mechanisms in the Three Chinese SOEs. 